\title{
Redescription and neotype designation for the poorly known fish parasitic cymothoid Joryma brachysoma (Pillai, 1964) (Crustacea: Isopoda) from India
}

\author{
Panakkool Thamban Aneesh, Ameri Kottarathil Helna and Appukuttannair Biju Kumar
}

Department of Aquatic Biology \& Fisheries, University of Kerala, Karyavattom, Thiruvananthapuram, Kerala, India.

\begin{abstract}
A neotype is designated for Joryma brachysoma (Pillai, 1964). The general morphology and appendages of the female and male stages are illustrated and re-described based on the neotype and several additional fresh specimens collected from the type host Pellona brachysoma Bleeker (=Sardinella brachysoma Bleeker) from nearby the type locality. The present redescription and neotype designation further resolves the taxonomic ambiguity regarding the species identification and conserves the name of J. brachysoma.
\end{abstract}

Keywords: branchial fish parasites, Cymothoidae, type locality, Sardinella brachysoma, Kerala coast.

The fish-parasitic isopod family Cymothoidae may be considered to have three major groups by site of attachment: external, buccal and gill-attaching; a fourth much smaller group are the flesh burrowing taxa (Brusca 1981). Joryma Bowman et Tareen, 1983, a genus restricted to the northern Indian Ocean, is branchial attaching. Most species in this genus are described from India except Joryma sawayah Bowman et Tareen, 1983, which was reported from Kuwait. The genus currently includes six valid species, among them two, Joryma tartoor (Pillai, 1954) and Joryma brachysoma (Pillai, 1964), have not been reported after their original descriptions.

Bowman and Tareen (1983) established the genus for $J$. sawayah, the type species and they transferred another three species from the genus Agarna Schiödte et Meinert, 1884 (A. engraulidis Barnard, 1936, A. tartoor Pillai, 1954 and A. brachysoma Pillai, 1964) into Joryma. Subsequently, Rameshkumar et al. (2011), described Joryma hilsae Rameshkumar, Ravichandran et Trilles, 2011. Aneesh et al. (2019) revised the genus and added Joryma malabaricus Aneesh, Helna et Trilles, 2019 into the genus and thus, the total number of species is now six.

The recent revision of the genus by Aneesh et al. (2019), includes the redescription of Joryma engraulidis (Barnard, 1936), J. hilsae and J. sawayah based on female and male stages, a neotype was designated for $J$. engraulidis, but the information and identity of $J$. brachysoma and $J$. tartoor are still based on Pillai's (1964) original description. There is no type or voucher material of J. brachysoma and designation of neotype is needed. In this paper, we are designat- ing a neotype for $J$. brachysoma and redescribe the species based on the neotype and additional specimens collected recently from the type host and type locality.

\section{MATERIALS AND METHODS}

Live specimens of Joryma brachysoma were collected from the Muttom fish landing center, southwestern coast of India $\left(8^{\circ} 07^{\prime} 48^{\prime \prime} \mathrm{N} ; 7^{\circ} 19^{\prime} 12^{\prime \prime} \mathrm{E}\right)$ and Mariyanadu fish landing centre, Trivandrum, Kerala coast $\left(8^{\circ} 35^{\prime} 56.5^{\prime \prime} \mathrm{N} ; 76^{\circ} 48^{\prime} 47^{\prime \prime} \mathrm{E}\right)$ in India. Specimens were removed from the branchial cavity of the host fish, fixed in 5\% formaldehyde and preserved in $75 \%$ ethanol. Methods for dissection, mounting and drawings of appendages were according to the techniques described in Aneesh et al. (2019). Drawings were digital-inked using Adobe Illustrator and WACOM CTL-472/K0-c drawing pad. The specimens were microphotographed using multi-focusing dissection microscope Leica-M205A and image capturing software (Leica Application Suit). Sources for fish taxonomy and host nomenclature were FishBase (Froese and Pauly 2019) and Catalogue of Fishes (Eschmeyer 2019). The types and voucher specimens are deposited in the Western Ghat Field Research Centre of the Zoological Survey of India, Kozhikode (ZSI/WGRC).

\section{RESULTS}

\section{Taxonomy}

Suborder Cymothoida Wägele, 1989

Superfamily Cymothooidea Leach, 1814 


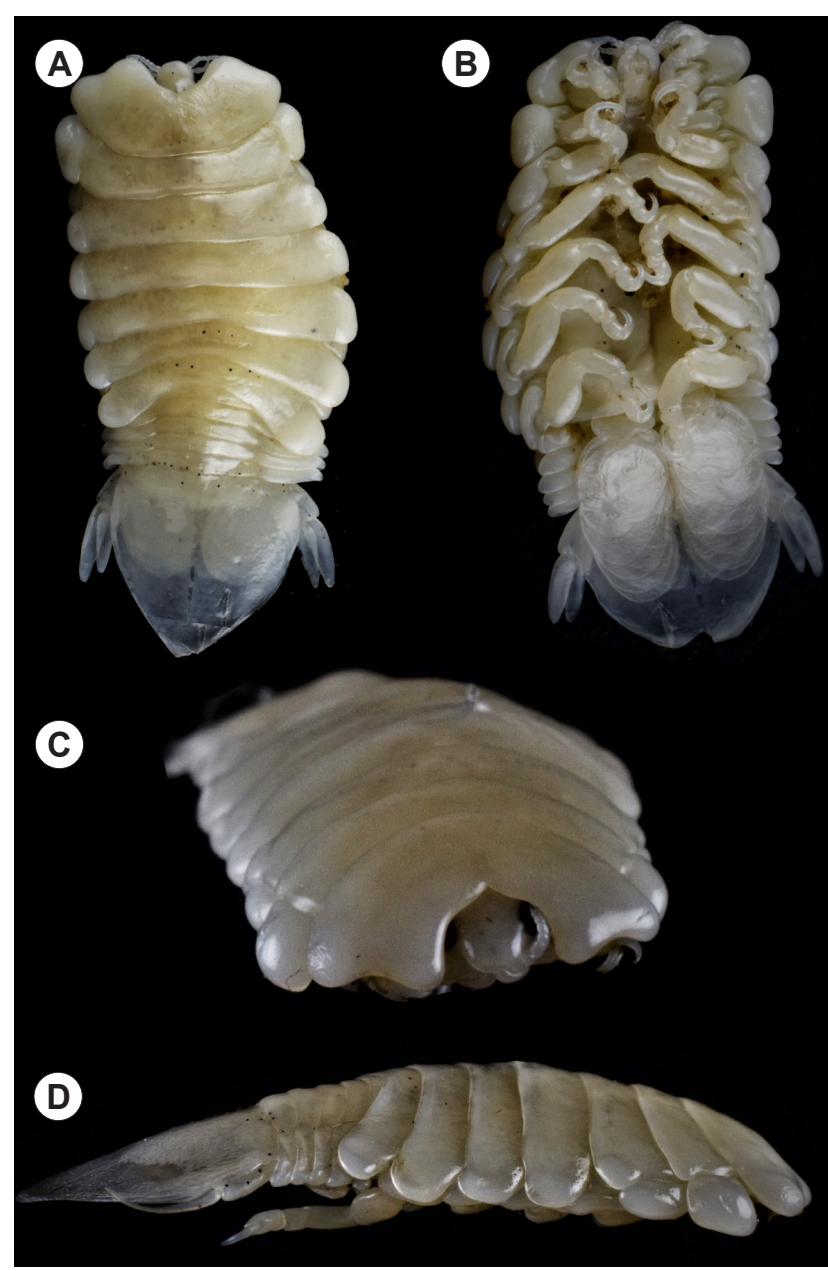

Fig. 1. Joryma brachysoma (Pillai, 1964), neotype female. A dorsal view; B - ventral view; C - dorsofrontal view; D - lateral view.

Family Cymothoidae Leach, 1818

Genus Joryma Bowman et Tareen, 1983

Joryma - Bowman et Tareen (1983): 21.

Aneesh et al. (2019): 1449-1478.

Agarna - Schiödte et Meinert (1884): 328-329 [partim]. Barnard (1936): 169; Pillai (1964): 211.

Type species: Joryma sawayah Bowman et Tareen, 1983, by original designation.

Species included: Agarna engraulidis Barnard, 1936; Agarna tartoor Pillai, 1954; Agarna brachysoma Pillai, 1964.

Remarks. A detailed generic diagnosis was provided for female, male and larvae by Aneesh et al. (2019). Jory$m a$ can be easily distinguished from other similar branchial cymothoid genera by the combination of the following characters: (1) asymmetrical and hunched body; (2) cephalon immersed in pereonite 1; (3) pereonite 1 anteriorly produced into lobe along one or both lateral margins of the head; (4) coxae of pereonites 2 and 3 medially expanded', much larger than remaining coxae and resembling the
A

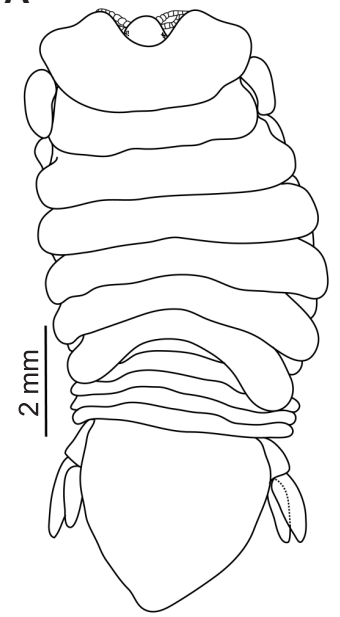

B
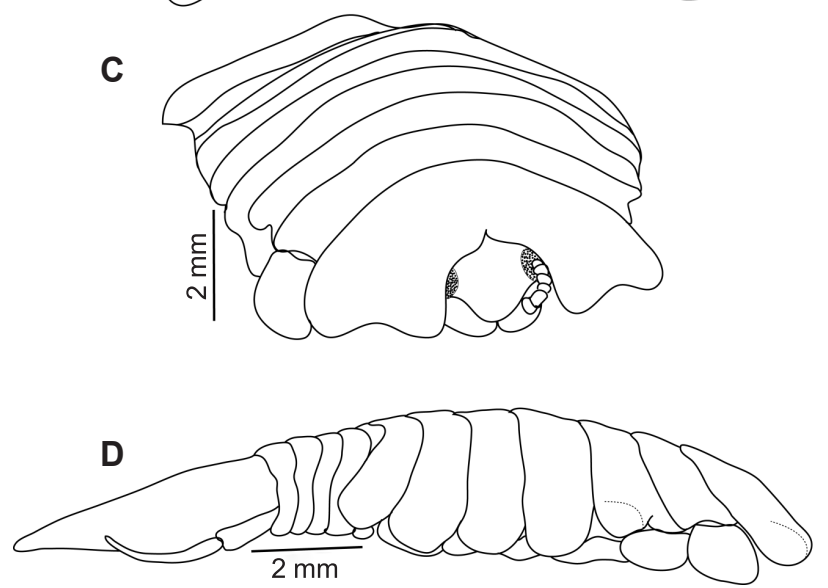

Fig. 2. Joryma brachysoma (Pillai, 1964), neotype female. A dorsal view; B - ventral view; C - dorsofrontal view; D - lateral view.

dorsolateral bosses ("ovarian bosses") of epicarideans; (5) mandible palp enlarged, very stout, unsegmented/distinctly or incompletely segmented; (6) maxilla with pectinate scales on both lobes; (7) brood pouch posteriorly covered by a pocket formed from sternite; (8) uropod rami equal or unequal, not reaching the posterior margin of pleotelson.

Neotype designation for Joryma brachysoma (Pillai 1964): Joryma brachysoma was described by Pillai (1964) as A. brachysoma. Joryma brachysoma was described by Pillai (1964) as A. brachysoma. The original description of the female was brief with few illustrations (dorsal view, antennula, antenna, mandible, maxillula, maxilliped, pereopod 1 and 7, uropod and dorsal view of male) and is no longer comparable in detail to more recent descriptions of the species in the genus. The type locality (Trivandrum, Kerala, India) and the type host (Pellona brachysoma Bleeker (=Sardinella brachysoma Bleeker), were clearly mentioned.

Pillai (1964) stated that the holotype female was deposited in the Indian Museum, Kolkata, but he did not give a registration number. Enquiries at the Indian Museum, Kolkata, failed to reveal any material that could be identified, or indeed even potentially considered as the type ma- 


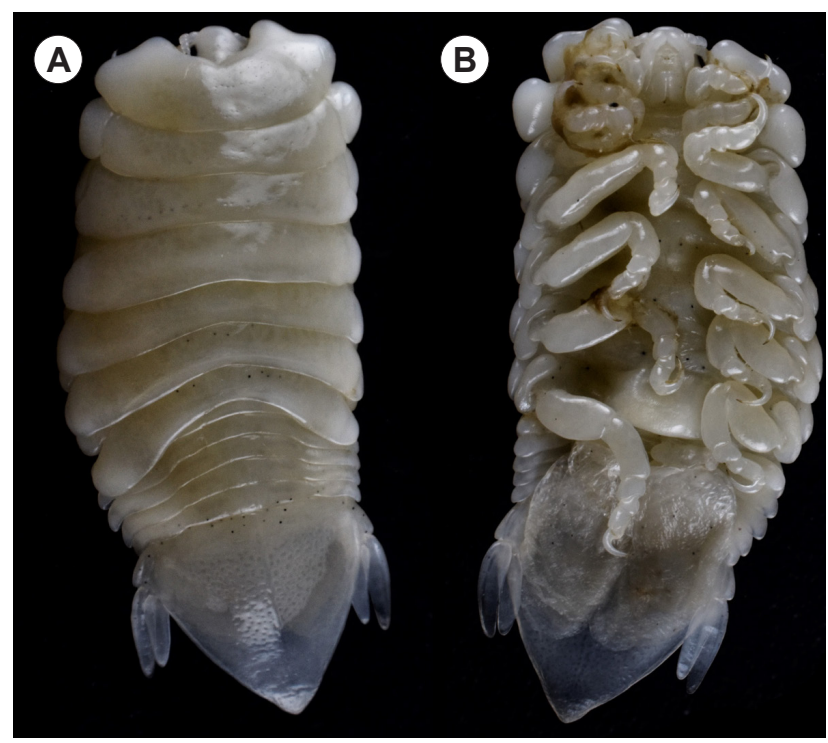

Fig. 3. Joryma brachysoma (Pillai, 1964), female. A - dorsal view; $\mathbf{B}$ - ventral view.

terial for J. brachysoma. It seems that the types were either lost or destroyed, or possibly never deposited.

There are no confirmed subsequent records of J. brachysoma (see Bowman and Tareen 1983) transferred this species into the new genus Joryma. Identity of J. brachysoma has been consistently problematic with most of the subsequent reports either misidentification, e.g. Rijin et al. 2019 (they misidentified Joryma malabaricus); Anandkumar et al. (2017) (= Catoessa gruneri Bowman et Tareen, 1983); Ravichandran et al. 2010 (= Catoessa boscii [Bleeker, 1857]); Ravichandran et al. 2009 (= Norileca indica [Milne Edwards, 1840]) or unconfirmed records (Veerappan and Selvamathi 2009). The identification of $J$. brachysoma at present rests only on the Pillai's original description and this species needs redescription to distinguish it from the other five species of the genus.

The new material of J. brachysoma described here was collected from the type host S. brachysoma from two different localities, Muttom fish landing centre, Tamil Nadu and Mariyanadu fish landing center, Trivandrum, both from southwestern coast of India. Mariyanadu is very close to the type locality of the Pillai's specimens (Trivandrum, Kerala coast, India). We consider the locality of neotype to be similar to the type locality "as nearly as practicable from the original type locality"(ICZN-Art. 75.3.6 1999).

All the present Indian material agrees well with the description and figures given by Pillai (1964): cephalon exposed dorsally; not reaching margin of pereonite 1 expansion, pereonite 1 anterolateral expansion bilateral and slightly bilobed; pleonites 1 and 2 laterally overlapped by pereonite 7; pleonite 1 slightly visible in dorsal view. Pleotelson round-triangular, uropods rami unequal, mandibular palp distinctly 3-segmented.

The present study is slightly smaller $(11.6 \mathrm{~mm})$ than the material studied by Pillai (1964; females $13.5 \mathrm{~mm}$ ). We are confident that the present material from India and Pil-

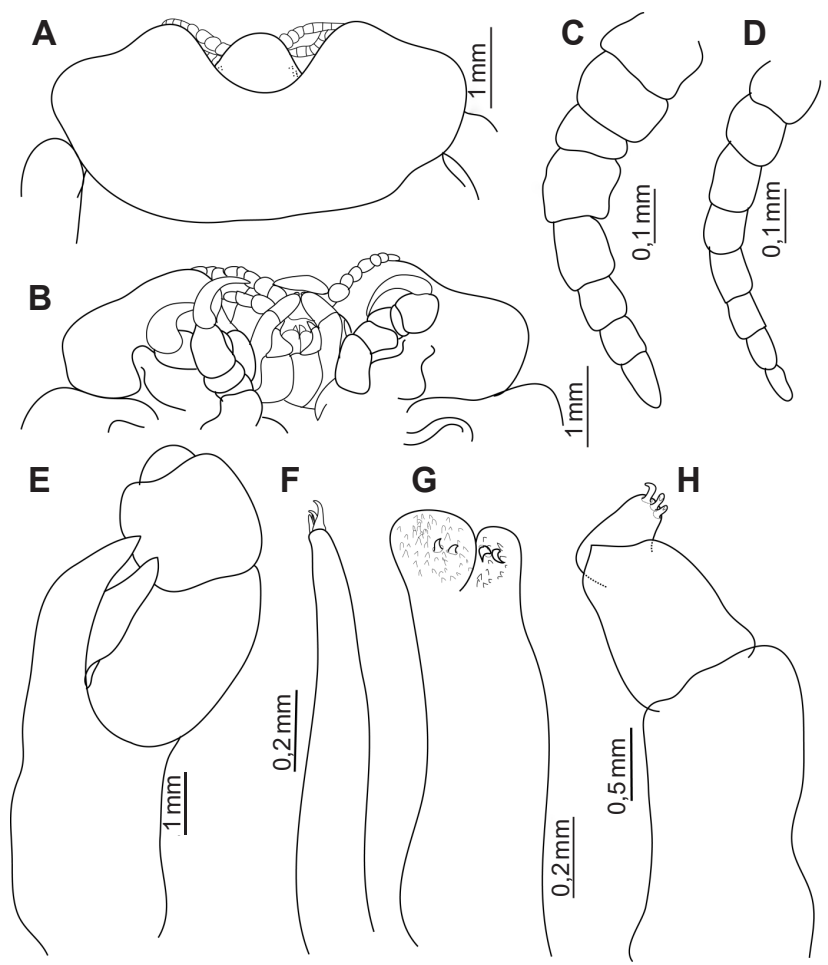

Fig. 4. Joryma brachysoma (Pillai, 1964) respectively female. A; $\mathbf{B}$ - cephalon, dorsal and ventral view; $\mathbf{C}$ - antennule; $\mathbf{D}$ - antenna; $\mathbf{E}$ - mandible; $\mathbf{F}$ - maxillule; $\mathbf{G}$ - maxilla; $\mathbf{H}$ - maxilliped.

lai's material are conspecific. Therefore, we here designate a neotype for future studies.

Joryma brachysoma (Pillai, 1964), Bowman et Tareen, 1983

Figs $1-8$

Agarna brachysoma Pillai, 1964 - Trilles 1994: 161.

Joryma brachysoma - Bowman and Tareen (1983); Laila (1995): 156; Aneesh et al. (2019): 1449-1478.

Excluded from synonymy: Joryma brachysoma of Rijin et al. (2019): 241-249, figs. b-d [= Joryma malabaricus Aneesh, Helna et Trilles, 2019]

Anand et al. 2017:55-61, fig. 2f [= Catoessa gruneri Bowman et Tareen, 1983]

Aneesh et al. (2016): 1270-1277, figs. 2d-g [= Joryma malabaricus Aneesh, Helna et Trilles, 2019]

Ravichandran et al. (2009): 80-84, fig. 1-2 [= Norileca indica (Milne Edwards, 1840).]

Ravichandran et al. (2010): 97-98, fig. 2 [= Catoessa boscii (Bleeker, 1857)]

Unconfirmed report: J. brachysoma of Veerappan and Selvamathi (2009): 416-424

Material examined: 13 우 (ovigerous - total length of $11.6,12.8$ and $13.2 \mathrm{~mm}$ ) (non-ovigerous $-10.5,11.0,11.6$, $11.5,12.0,12.0,12.0,12.0,13.4$ and $13.6 \mathrm{~mm})]$ and $3 \hat{\delta} \widehat{\partial}$ (8.0, 9.0 and $8.0 \mathrm{~mm})$.

$\mathrm{N}$ e otype : 1 ㅇ (ovigerous, $11.6 \mathrm{~mm}$ ), Mariyanadu fish landing centre, Trivandrum, Kerala Coast (Reg. No. ZSI/WGRC/IR/ INV/12289) from S. brachysoma, collected by P.T. Aneesh, date of collection 13 May 2018, host size $10.5 \mathrm{~cm}$.

Vou chers : All from S. brachysoma collected by P.T. Aneesh, 


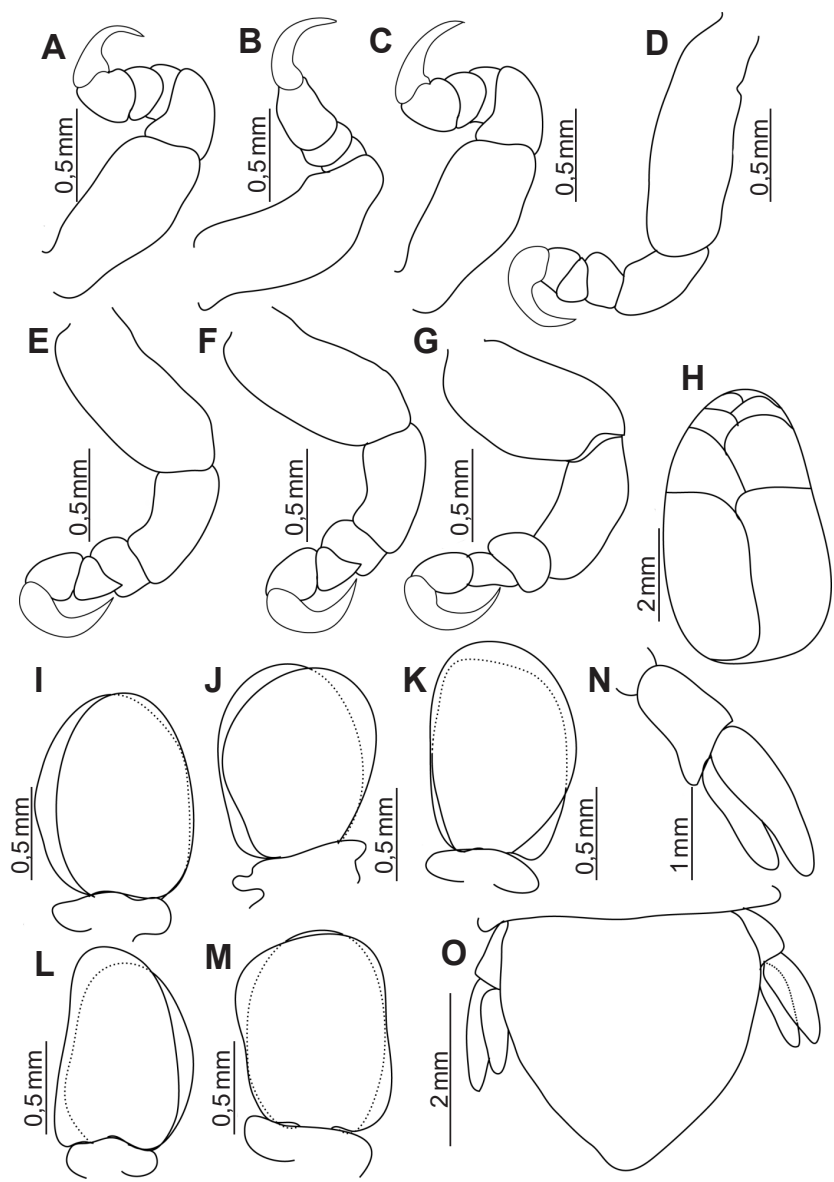

Fig. 5. Joryma brachysoma (Pillai, 1964), female, dorsal view. A- $\mathbf{G}$ - pereopods $1-7 ; \mathbf{H}$ - brood pouch; $\mathbf{I}-\mathbf{M}$ - pleopods $1-5$; $\mathbf{N}$ - uropod; $\mathbf{O}$ - pleotelson and uropods.

1 오 (non-ovigerous, $12 \mathrm{~mm}$ ) Muttom, southwestern coast of India (Reg. No. ZSI/WGRC/IR/INV/12290); 1 ઈ (8 mm) same information of neotype (Reg. No. ZSI/WGRC/IR/INV/12291).

Description of female neotype (Figs 1-5). Body about 2.0-2.3 times longer than wide, slightly asymmetrical, widest at pereonite 5. Cephalon anterior margin rounded, dorsally conspicuous, not reaching margin of pereonite 1 expansion. Eyes slightly visible, dorsal side. Pereonite 1 moderately expanded and longest. Pereonite 1 anterolateral expansion bilateral and slightly bilobed, on 3-6 subequal in length. Pereonites 2 and 7 slightly shorter than 4 . Coxae 2 clearly visible dorsally, much enlarged produced anteriorly. Coxae 3-7 partly visible dorsally in hunched side. Pleonites 1, 2 and one side of pereonite 3 overlapped laterally by pereonite 7 . Pleonites $1-5$ subequal in length and width, lateral margin of pleonites slightly curving posteriorly. Pleotelson as long as wide, subacute with apex round. Pleotelson narrower than pleonite 5.

Antennula with 8 articles. Antenna with 8 articles, narrower than antennula, article 3 longest. Mandible with slightly curved and apically acute incisor, palp stout, distinctly 3-articled. Article 1 broader and longer than other articles; article 2 equal in width and 0.5 times the length of article 1; article 3 short and conical. Maxillula with 4 unequal slightly recurved apical robust setae. Maxilla with

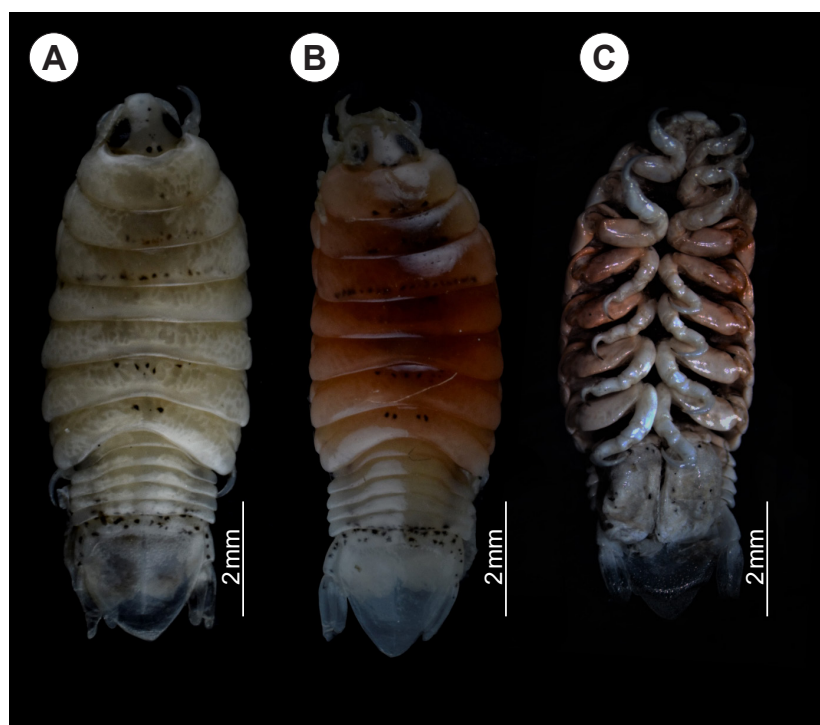

Fig. 6. Joryma brachysoma (Pillai, 1964), males. A, B - dorsal view; $\mathbf{C}$ - ventral view.

2 apical robust setae on both median lobe and lateral lobe. Maxilliped without oostegial lobe; article 3 with 3 apical robust setae.

Pereopods 1-3 subequal in length; pereopod 1 basis 2 times as long as greatest width; ischium 2 times longer than as basis; propodus as long as wide. Dactylus of pereopod 1-3 reaches up to merus. Pereopods 4-7 subequal in length. Pereopods basis gradually decrease in length and increase in width from pereopods 4-7. Pereopod 4 basis 2.7 times wide, pereopod 6 basis 1.9 times as long as wide. Pereopod 7 basis 1.5 times longer than greatest width. Ischium gradually increase in length from 4-7. Dactylus of pereopod 4-7 shorter than 3 .

Pleopod 1 exopod 1.6 times longer than wide, lateral margin convex, distally broadly rounded, mesial margin weakly produced; endopod 1.7 times longer than wide, distally narrowly rounded; without retinaculae. Pleopods 2-5 similar to pleopod 1. Peduncles of pleopods expanded laterally into rounded lobes. Exopods of pleopods 3-5 with triangular proximolateral lobes. Uropod 0.6 times longer than the length of pleotelson, peduncle 1.8 times longer than endpod, peduncle lateral margin without setae. Endopod apically slightly pointed, lateral margin weakly convex, mesial margin weakly convex. rami unequal, exopod 1.2 times longer than endopod.

Brood pouch is typical for the genus.

Male (Figs 6-8). Smaller than female, body symmetrical, 2.5 times longer than wide, widest at pereonite 6. Cephalon sub-triangular with round anterior margin, 1.1 times wider than long, immersed in pereonite 1 to some extent. Eyes, prominent representing 30\% of width of cephalons. Pereonite 1 anterolateral margins not produced; pereonite 1 longest, 7 shortest, 2-6 subequal. Coxae 2 and 3 clearly visible dorsally. Pleonite 1 overlapped laterally by pereonite 7. Pleonites subequal in length and width, lateral margins slightly directed posteriorly. Pleotelson as long as 

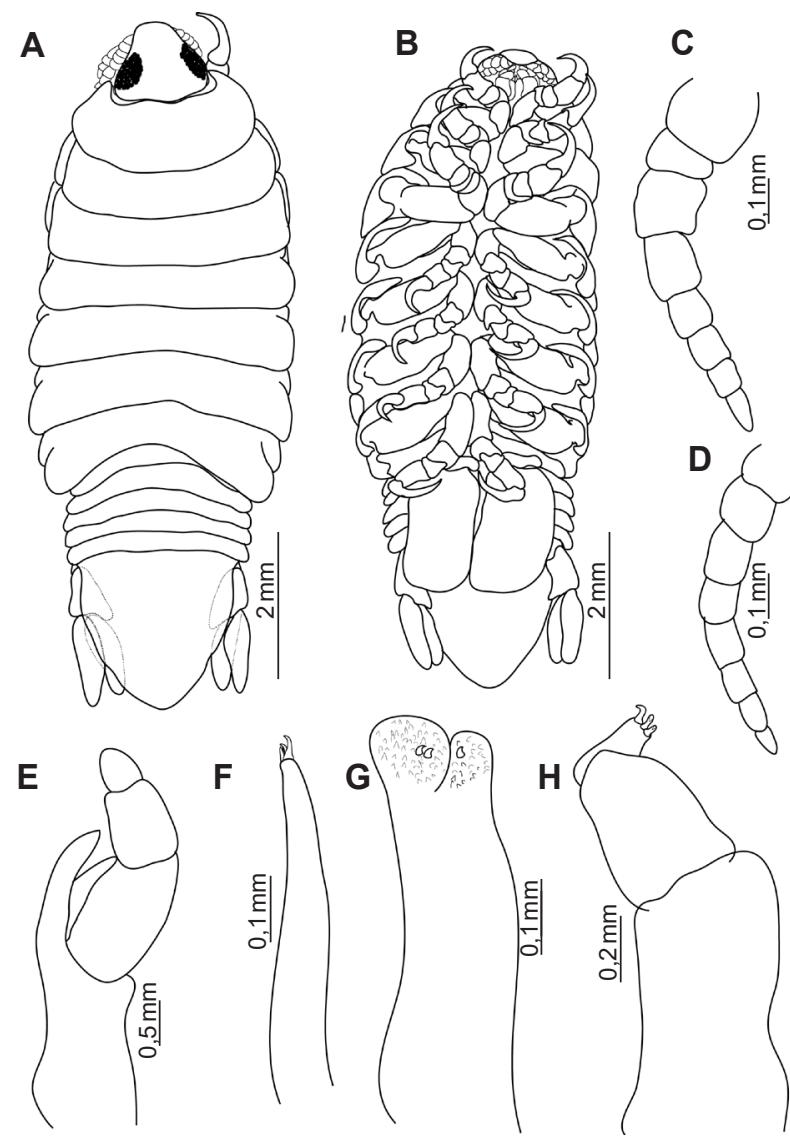

Fig. 7. Joryma brachysoma (Pillai, 1964) male. A - dorsal view; B - ventral view; C - antennule; D - antenna; $\mathbf{E}$ - mandible; $\mathbf{F}$ maxillule; $\mathbf{G}$ - maxilla; $\mathbf{H}$-maxilliped.

wide, slightly narrower than pleonite 5 with posterior margin broadly triangular.

Antennula with 8 articles, distinctly stouter than antenna. Antenna, 8-articled, narrower than antennula, article 3 longest. Maxillule and maxilliped similar to those with of female. Mandible palp narrower than female, Maxilla, inner lob with one and outer lobes with two robust setae.

Pereopods slightly increasing the size from $1-7$. Penes, a pair of small tubercles visible on surface of sternite 7 , medially united with minute opening at the apex. Appendix masculina of pleopod 2, straight, slightly shorter than endopodite and tapering gradually to narrow apex. peduncles of pleopods with few small setae. Uropods slightly shorter than pleotelson; rami unequal in length, curved and apically rounded, exopod longer than endopod.

Size: Ovigerous females $(11.6-13.2 \mathrm{~mm}$; average $12.5 \mathrm{~mm})$, non-ovigerous females $(10.5-13.6 \mathrm{~mm}$; average $12.0 \mathrm{~mm})$, male (body length in $\mathrm{mm}, 8-9 \mathrm{~mm}$; average 8.3 ).

C o lo u r: Male and female, live colour is white.

H o st: Sardinella brachysoma Bleeker (Pillai 1964; Ravichandran et al. 2009; Laila 1995; Present study).

Distribution: Recorded from Trivandrum, Kerala coast, Arabian Sea (Pillai 1964; Laila 1995); Parangipettai, Tamil Nadu, Southeast coast of India (Ravichandran et al. 2009); Present Indian materials are from, Muttom, Southwest coast of India and Mariyanadu, Trivandrum, Kerala coast.
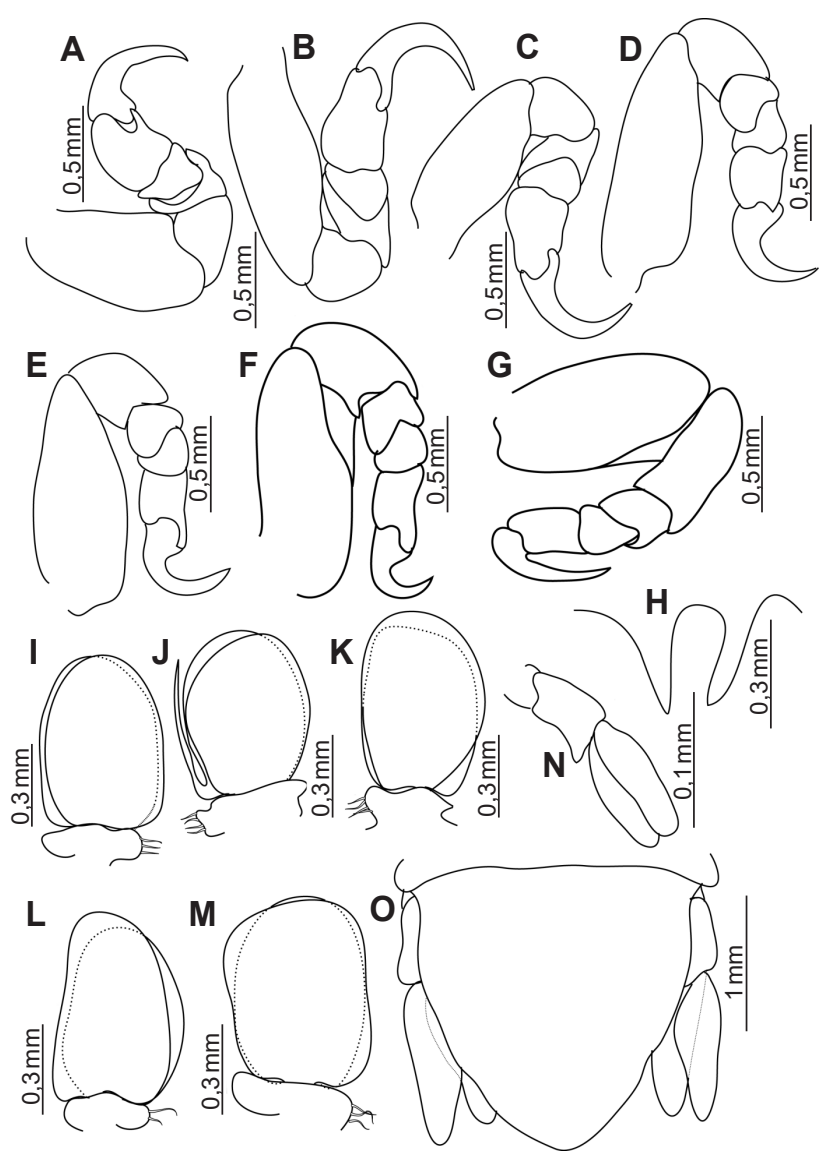

Fig. 8. Joryma brachysoma (Pillai, 1964) male. A-G - pereopods $1-7 ; \mathbf{H}$ - penes; $\mathbf{I}-\mathbf{M}$ - pleopods $1-5 ; \mathbf{N}$ - uropod; $\mathbf{O}$ - pleotelson and uropods.

\section{DISCUSSION}

The best combination of characters for identification of Joryma brachysoma are: cephalon not reaching the margin of pereonite 1 expansion; pereonite 1 anterolateral expansion bilateral and slightly bilobed; pleonite 1 entirely overlapped by pereonite 7 and not visible in dorsal view; pleotelson sub-triangular, uropods rami unequal in length, exopod 1.2 times longer than endopod; mandibular palp distinctly 3 -segmented.

Joryma brachysoma can be separated from its congeners by the following combination of characters: in J. malabaricus, the cephalon is conspicuous dorsally, extending beyond the pereonite 1 ( $v s$ cephalon not reaching the pereonite 1), pereonite 1 antero-lateral expansion unilateral and not bilobed ( $v s$ bilateral and slightly bilobed in J. brachyso$m a$ ), the mandible palp not segmented (vs distinctly 3 segmented in J. brachysoma ). In Joryma sawayah, pleotelson is triangular ( $v s$ subacute with the apex round in J. brachysoma), mandible palp is unsegmented (vs distinctly 3-segmented in J. brachysoma ); in Joryma tartoor, cephalon is covered dorsally by pereonite 1 ( $v s$ cephalon conspicuous dorsally in J. brachysoma), antenna 9- or 10- segmented (vs eight in J. brachysoma). In Joryma hilsae, the cephalon is reaching the pereonite 1 ( $v s$ cephalon not reaching the pereonite 1 in $J$. brachysoma), uropod rami equal (vs unequal in J. brachysoma). In Joryma engraulidis, the cephalon is reaching beyond pereonite 1 (vs not reaching 
the pereonite 1 in J. brachysoma), anterolateral expansion of pereonite 1 unilateral and not bilobed ( $v_{s}$ bilateral and slightly bilobed in J. brachysoma).

Joryma brachysoma has been widely misidentified (as discussed by Aneesh et al. 2019). The present redescription based on the neotype and non-type specimens provides precise diagnosis of $J$. brachysoma.

Acknowledgements. The authors acknowledge the D.S. Kothari Post-Doctoral Fellowship of University Grants Commission, New Delhi (No. F.4-2/2006 (BSR)/BL/16-17/0401) awarded to PTA.
We extend our sincere thanks to Dr. Charles Oliver Coleman, Curator of the crustacean collection, Museum für Naturkunde Leibniz Institute, Berlin, Germany, for teaching the technique of digital inking and DELTA to PTA. We sincerely acknowledge the Director, Zoological Survey of India, Kolkata and scientists and assistant zoologist in the Crustacea section of the Indian Museum, Kolkata for the provision of facilities to carry out the museum search for the current research work. Further, we gratefully acknowledge the effort made by two anonymous reviewers for their critical reviewing of the manuscript and making valuable suggestions for the improvement of the manuscript

\section{REFERENCES}

Anandiumar A., Rameshiumar G., Ravichandran S., NaGarajan R., Prabakaran K., Ramesh M. 2017: Distribution of isopod parasites in commercially important marine fishes of the Miri coast, East Malaysia. J. Parasit. Dis. 41: 55-61.

Aneesh P.T., Helna A.K., Trilles J.P., Chandra K. 2019: A taxonomic review of the genus Joryma Bowman and Tareen, 1983 (Crustacea: Isopoda: Cymothoidae) parasitizing the marine fishes from Indian waters, with a description of a new species. Mar. Biodiv. 49: 1449-1478

Aneesh P.T., Helna A.K., Kappalli S. 2016: Branchial cymothoids infesting the marine food fishes of Malabar coast. J. Parasit. Dis. 40: 1270-1277.

BARNARD K.H. 1936: Isopods collected by the R.I.M.S. Investigator. Rec. Indian Museum 38:1 47-191.

Bowman T.E., Tarren I.U. 1983: Cymothoidae from fishes of Kuwait (Arabian Gulf) (Crustacea, Isopoda). Smiths. Contr. Zool 382: 1-30.

BrusCA R.C. 1981: A monograph on the Isopoda Cymothoidae (Crustacea) of the eastern Pacific. Zool. J. Linn. Soc. 73: 117-199.

Eschmeyer W.N. 2019: Catalog of fishes: Genera, species, reference. Available from: http://researcharchive.calacademy.org/ research/ichthyology/catalog/fishcatmain.asp

Froese R., Pauly D. (Eds.) 2019: FishBase. Version (02/2015) World Wide Web electronic publication. Available from: http:// www.fishbase.org.

LAILA B.M. 1995: Studies on the isopod fish parasites of Kerala and environ. Aquatic Biology and Fisheries, University of Kerala. PhD thesis, $156 \mathrm{pp}$.
Pillai N.K. 1964: Parasitic isopods of the family Cymothoidae from South Indian fishes. Parasitology 54: 211-223.

Rameshiumar G., Ravichandran S., Trilles J.P. 2011: Cymothoidae (Crustacea, Isopoda) from Indian fishes. Acta. Parasitol. 56: 78-91.

RaVichandran S., Rameshiumar G., Balasubramanian T. 2010: Infestation of isopod parasites in commercial marine fishes. J. Parasit. Dis. 34: 97-98.

Ravichandran S., Rameshimumar G., Mahesh B., KumarAVEL K. 2009: Infestation of Rastrelliger kanagurta, with cymothoid isopod Joryma brachysoma in the Colachel environment of Southwest coast of India. W. J. F. M. S. 1: 80-84.

Rijin K., Sudha K., Vineesh P.J., Anilkumar G. 2019: Seasonal variation in the occurrence of parasitic isopods and copepods (Crustacea) infecting the clupeidaen fishes of Malabar Coast, India. Turk. J. Fish. Aquat. Sci. 19: 241-249.

Schiödte J.C., Meinert F. 1884: Symbolae ad Monographiam Cymothoarum Isopodum Familiae 4. Cymothoidae. Trib. II. Cymothoinae. Trib. III. Livonecinae. Naturhist Tidsskr 14: 221-454.

Trilles J.P. 1994: Les Cymothoidae (Crustacea, Isopoda) du monde. Prodrome pour une faune. Stud. Mar. 21/22 (1991): 5-288

Veerappan N., Selvamathi A. 2009: Parasitic fauna of fishes. Centre of Advanced Study in Marine Biology Annamalai University, pp. 416-424.

WëGELE J.-W. 1989: Evolution und phylogenetisches System der Isopoda. Stand der Forschung und neue Erkenntnisse. Zoologica 140: $1-262$.

Cite this article as: Aneesh P.T., Helna A.K. and Kumar A.B. 2019: Redescription and neotype designation for the poorly known fish parasitic cymothoid Joryma brachysoma (Pillai, 1964) (Crustacea: Isopoda) from India. Folia Parasitol. 66: 014. 